The use of various forms of public participation in decision-making by public authorities is becoming more common in the process of civil society development in Ukraine. Public discussions are one of these forms.

The effectiveness of the use of public discussions depends on the degree of legal regulation in Ukraine. In this regard, there is a need to analyze the constitutional and legal regulation of public discussions in Ukraine. Some legal acts regulating public discussions in Ukraine are declarative in nature, since there is no legal regulation of the procedure for holding such discussions.

In Ukrainian law, similar terms are used: "public hearings", "public hearings", "open meetings", "public meetings", "public consultations" and others, which creates some ambiguity and difficulty in understanding.

The result of public discussions is not normally mandatory for public authorities. Public discussion enhances the connection between government and society, creates an additional opportunity for authorities to make their own decisions to satisfy the interests of the public, or to make decisions based on public opinion.

Key words: public, public discussions, constitutional and legal regulation, Ukraine.

DOI: $10.33766 / 2524-0323.88 .35-45$

УДК 342.3

О. М. Діденко,

аспірант кафедри конституційного права

та прав людини

Національної академії внутрішніх справ

(м. Київ, Україна)

e-mail: odm20@ukr.net

iDhttps://orcid.org/0000-0002-2279-947X

\title{
ЕВОЛЮЦІЯ РОЗВИТКУ ВИБОРЧОГО ЗАКОНОДАВСТВА УКРАЇНИ
}

У статті розкриваються особливості становлення виборчого законодавства України з часу проголошення незалежності нашої держави. Виокремлено певні тенденції й закономірності його еволюційного шляху розвитку. Так вибори Президента України, народних депутатів України, як і місцеві вибори органів і посадових осіб місцевого самоврядування проводилися переважно на основі нових законів чи їх нових редакцій, апробуючи різні види виборчих систем. Виокремлено певні етапи і позитивну динаміку до стабільності виборчого законодавства України в останні роки. Наголошено значення Виборчого кодексу України для упорядкування даної галузі законодавства, гармонізації 3 існуючими міжнародними стандартами в цій сфері, а також визначено перспективні напрями удосконалення виборчого законодавства.

Ключові слова: вибори, законодавство, періодизація, право обирати, вибори Президента України, місцеві вибори, Виборчий кодекс України.

Постановка проблеми. 3 проголошенням незалежності держави, звісно, актуалізується питання розбудови системи організації публічної влади, створення демократичних інституцій, відповідної національної правової системи поряд з економічною, політичною, культурною чи ідеологічною тощо. Вибори, як один з основних інститутів прямого народовладдя, а також дієвих,

() Діденко О. М., 2019 
поширених і найдавніших його форм в Україні та переважній більшості країн сучасного світу, дозволяють громадянам реалізувати власне право обирати та бути обраним до органів державної влади та місцевого самоврядування. Тим самим забезпечується здійснення конституційно гарантованих прав і свобод людини й громадянина, легітимації влади. У свою чергу, зі зміною політичної чи іншої системи суспільства й держави, державного устрою, різновидів форми правління й умов змінюється, доповнюється чи взагалі приймається нове виборче законодавство. Україна при цьому не $є$ винятком, а українські реалії демонструють кардинальну модернізацію даної галузі законодавства [17].

Аналіз останніх досліджень і публікацій. Законодавча основа виборів як інституту безпосередньої демократії в Україні неодноразово ставала предметом наукових розвідок. Значний інтерес дослідників в Україні, насамперед ученихконституціоналістів, муніципалістів, політологів та ін., спостерігався переважно після прийняття Конституції України, наприкінці 90-х років XX ст. - початку XX ст. Він характерний для сучасних умов, і це засвідчують праці таких авторів, як М. Баймуратов, В. Демиденко, Н. Камінська, В. Кампо, Ю. Ключковський, Р. Князевич, М. Козюбра, Л. Кривенко, П. Мартиненко, О. Марцеляк, В. Нестерович, I. Панкевич, А. Селіванов, С. Серьогіна, М. Смокович, О. Совгиря, М. Ставнійчук, А. Стрижак, Ю. Тодика, В. Федоренко, О. Фрицький, В. Шаповал та ін.

У їхніх наукових роботах переважно висвітлюються питання безпосередньої демократії, виборчого права, виборчих систем, виборчого процесу, міжнародноправових стандартів у цій сфері, доцільності прийняття Виборчого кодексу тощо. Водночас у працях дослідників недостатньо уваги приділено саме питанням узагальненню вітчизняного історичного досвіду законодавчого регулювання виборів, прийняття і реалізації виборчого законодавства як у нашій державі, так і відповідної зарубіжної практики.

Формування цілей. Метою даної статті є дослідження еволюційного процесу розвитку виборчого законодавства України, виокремлення певних тенденцій і закономірностей, а також визначення перспективних напрямів його удосконалення.

Виклад основного матеріалу. Становлення нової незалежної Української держави розпочалося на основі діючого на той час радянського законодавства. 3 огляду на це, історія виборчого процесу України і виборчого законодавства пов'язана 3 двома різними основними законами - Конституцією (Основним Законом) Української РСР, прийнятою 20 квітня 1978 року [1] та Конституцією України, прийнятою 28 червня 1996 року [2]. Перша втратила чинність у 1996 році, тому ऑï норми мали безпосереднє відношення до правового регулювання ряду виборчих кампаній, які відбулися в Україні напередодні та в перші роки ії незалежності. Це вибори народних депутатів СРСР (1989), вибори народних депутатів УРСР та України $(1990,1994)$, вибори Президента України (1991, 1994), місцеві вибори $(1990,1994)$.

До глави 6 «Основні права, свободи і обов'язки громадян України» та глави 10 «Виборча система» Конституції Української РСР тричі вносилися зміни - у 1989, 1991 та 1992 роках. Так за ст. 46 глави 6 передбачалося право громадян України брати участь в управлінні державними й громадськими справами, в 
обговоренні й прийнятті законів та рішень загальнодержавного й місцевого значення. Це право забезпечувалося можливістю обирати й бути обраними до Рад народних депутатів та інших виборних державних органів, брати участь у всенародних обговореннях і голосуваннях, у народному контролі, у роботі державних органів, громадських організацій та органів громадської самодіяльності, у зборах трудових колективів та за місцем проживання.

У свою чергу статті 84 - 88 глави 10 остаточної редакції Конституції 1978 р. закріплювали та визначали загальне, рівне і пряме виборче право, забороняли контроль за волевиявленням, вказуючи, що голосування мало б проводитися таємно. Серед іншого, встановлювались обмеження пасивного виборчого права (судді й арбітри арбітражних судів не могли бути народними депутатами, у виборах заборонялося брати участь психічно хворим громадянам, визнаним судом недієздатними; особам, які тримаються в місцях позбавлення волі, а також особам, які знаходяться за рішенням суду на примусовому лікуванні). Також було проголошено принципи рівного, прямого, таємного виборчого права, основні засади організації виборчого процесу, зауважуючи, що порядок проведення виборів народних депутатів визначається законами України. У статті 91 зберігався такий інститут як накази виборців, що були закладені в основу діяльності усіх виборних осіб [1].

Із запровадженням в Україні поста Президента Української РСР Конституція була доповнена Главою 12-1 «Президент України», норми якої визначали основоположні принципи виборів Президента України (загального, рівного і прямого виборчого права при таємному голосуванні) та вказували, що порядок проведення виборів визначається Законом «Про вибори Президента України». Як зазначають деякі дослідники, засади тогочасного виборчого права в цілому відповідали світовим демократичним традиціям [3-4], проте мали й власні особливості, зокрема вже згадані накази виборців тощо.

Спеціальне виборче законодавство, слід констатувати, було численним i включало: 1) Закон Союзу РСР № 9855-XI «Про вибори народних депутатів СРСР» від 1 грудня 1988 року, 2) Закон Української РСР № 8304-XI «Про вибори народних депутатів Української РСР» від 27 жовтня 1989 року; 3) Закон України №3623-XII «Про вибори народних депутатів України» від 18 листопада 1993 року; 4) Закон Української РСР № 1297-XII «Про вибори Президента Української РСР» від 5 липня 1991 року; 5) Закон Української РСР № 8305-XI «Про вибори депутатів місцевих Рад народних депутатів Української РСР» від 27 жовтня 1989 року; 6) Закон України № 3996-XII «Про вибори депутатів та голів сільських, селищних, районних, міських, районних у містах, обласних Рад» від 24 лютого 1994 року.

За останні майже тридцять років відбулося більше двадцяти виборчих кампаній, i, як бачимо, з вище наведеного переліку законів, які регулювали вибори в Україні, існують очевидні суттєві відмінності в існуючих виборчих системах, органах державної влади та місцевого самоврядування, до яких проводилися вибори, виборчому процесі тощо. 3 огляду на те, що діяла Конституція Української РСР і деякі закони Української РСР, приймалися нові закони, неодноразово вносилися зміни й доповнення в існуючі нормативноправові акти в даній сфері. 
Згодом, у період реформування державного апарату, загалом системи організації та функціонування публічної влади в Україні, іiї правової системи було прийнято Конституцію України від 28 червня 1996 року. Тут правовому регулюванню виборчого процесу присвячено низку статей у розділах, що безпосередньо стосуються виборних органів влади і відповідних посадових осіб (Президента України, Верховної Ради України та органів місцевого самоврядування), а також окремий розділ - Розділ III «Вибори. Референдум». Зокрема, ст. 69 цього розділу визначає, що народне волевиявлення здійснюється через вибори, референдум та інші форми безпосередньої демократії. Ст. 70 встановлює обмеження й вимоги до виборців - віковий ценз для набуття активного виборчого права у вісімнадцять років та обмеження права голосу в громадян, яких визнано судом недієздатними. Основні засади виборів, принципи проведення виборів встановлено ст. 71 Конституції України: вибори $є$ вільними і відбуваються на основі загального, рівного і прямого виборчого права шляхом таємного голосування; виборцям гарантується вільне волевиявлення. Ст. 76 Розділу IV «Верховна Рада України» встановлено засади виборів народних депутатів України (обираються на основі загального, рівного і прямого виборчого права шляхом таємного голосування строком на п'ять років). Ця ж стаття встановлює деякі обмеження права бути обраним (для реалізації пасивного виборчого права) - віковий ценз у двадцять один рік та ценз осілості (особа має проживати в Україні протягом останніх п'яти років), забороняється обрання народними депутатами України громадян, які мають судимість за вчинення умисного злочину, якщо ця судимість не знята у встановленому законом порядку.

Відповідні конституційні положення закріплено й стосовно засад виборів Президента України (ст. 106). Також визначено, що порядок проведення виборів Президента України встановлюється законом. У свою чергу, у статті 136 Конституції визначено, що Верховна Рада АРК є iї представницьким органом, депутати якої обираються на основі загального, рівного, прямого виборчого права шляхом таємного голосування. Строк повноважень Верховної Ради Автономної Республіки Крим, депутати якої обрані на чергових виборах, становить п' ять років [2].

Стосовно системи місцевого самоврядування, то Конституцією України у ст. 141 Розділу XI «Місцеве самоврядування» закріплено, що до складу сільської, селищної, міської, районної, обласної ради входять депутати, які обираються жителями села, селища, міста, району, області на основі загального, рівного, прямого виборчого права шляхом таємного голосування. Строк повноважень сільської, селищної, міської, районної, обласної ради, депутати якої обрані на чергових виборах, становить п'ять років. Територіальні громади на основі загального, рівного, прямого виборчого права відповідно обирають сільського, селищного, міського голову шляхом таємного голосування [2].

На розвиток згаданих конституційних положень прийнято низку спеціальних законів, інших нормативно-правових актів України. У даному контексті слід згадати:

- Закон України № 541/97-ВР «Про вибори народних депутатів України» від 24 вересня 1997 року; 
- Закон України № 2766-III «Про вибори народних депутатів України» від 18 жовтня 2001 року;

- Закон України № 474-XIV «Про вибори Президента України» від 5 березня 1999 року;

- Закон України № 118/98-ВР «Про вибори депутатів Верховної Ради Автономної Республіки Крим» від 12 лютого 1998 року;

- Закон України № 14/98-ВР «Про вибори депутатів місцевих рад та сільських, селищних, міських голів» від України 14 січня 1998 року;

- Закон України № 2487-VI «Про вибори депутатів Верховної Ради Автономної Республіки Крим, місцевих рад та сільських, селищних, міських голів» від 10 липня 2010 року;

- Закон України № 595-VIII «Про місцеві вибори» від 14 липня 2015 року;

- Виборчий кодекс України № 396-IX від 19 грудня 2019 року та ін.

У 2011 та 2014 роках були внесені зміни до Конституції України щодо строку повноважень органів та осіб місцевого самоврядування, таким чином змінювалася періодичність проведення місцевих виборів. Окрім того, до Конституції України було внесено зміни, за якими строк повноважень народних депутатів України, депутатів місцевих рад, а також сільських, селищних, міських голів було збільшено 34 до 5 років. До того ж, із метою одночасного проведення чергових місцевих виборів на всій території України, було скориговано відповідні конституційні положення ст. 141 Конституції України. Зауважимо, що більшість із вищезгаданих законів неодноразово зазнавали суттевих змін і доповнень шляхом узгодження з іншими законами України.

Не оминули ці процеси і виборів Президента України, адже якщо перші вибори Президента України 1991 р. відбувалися за Законом Української РСР «Про вибори Президента Української РСР» від 5 липня 1991 р., то вибори Президента України 1994 р. відбулися за новою, кардинально відмінною від попередньої, редакцією цього Закону 1994 р. Наступні вибори 1999 р., порядок проведення яких регламентувався Законом України № 474-XIV «Про вибори Президента України» від 5 березня 1999 р., вибори Президента України 2004 р. відбувалися за оновленою редакцією Закону. У 2004 році з метою урегулювання правової колізії, так званого «третього туру», для проведення повторного другого туру президентських виборів прийнято було спеціальний Закон України «Про особливості застосування Закону України «Про вибори Президента України» при повторному голосуванні 26 грудня 2004 року» [39], який діяв лише під час проведення повторного другого туру виборів та відразу після підбиття підсумків виборів утратив свою чинність. Останні президентські вибори (2019рр.) проводилися, як і попередні (2014 р.), за Законом України «Про вибори Президента України» 1999 р. у редакції від 28.02. 2019 р. [7-9].

Незважаючи на це, виборча система з виборів Президента України не змінювалася, застосовувалася мажоритарна виборча система абсолютної більшості, проте змінювалися виборчі процедури, оптимізовано територіальну організацію виборів та управління виборчим процесом, вживалися заходи щодо припинення зловживань і недопущення фальсифікацій з боку окремих суб'єктів виборчого процесу. 
Окремі із внесених змін до виборчого законодавства відзначалися кардинальним характером, що фактично змінювали самі базові закони. Так, починаючи з 1989 р., в Україні відбувалося десять виборчих кампаній із виборів народних депутатів України (включаючи вибори народних депутатів УРСР та СРСР), які регулювалися шістьма базовими виборчими законами (без урахування численних змін та доповнень, які вносилися в кожну з цих базових редакцій виборчих законів). Виборче законодавство щодо місцевих виборів (виборів депутатів місцевих рад та депутатів Верховної Ради Автономної Республіки Крим, а також голів рад та сільських, селищних та міських голів) також регулярно, практично до кожних чергових виборів, змінювалося.(Детальніше на особливостях еволюції виборчого законодавства України стосовно народних депутатів України і місцевих виборів зупинимось у наступних публікаціях).

На нашу думку, принциповій новелізації виборчого законодавства України сприяли розробка і прийняття Законів України «Про Центральну виборчу комісію» від 30 червня 2004 р. № 1932-IV, «Про Державний реєстр виборців» від 22 лютого 2007 р. № 698-V, Виборчого кодексу України від 19 грудня 2019 р. № 396-IX.

У науковому середовищі точилися тривалий час дискусії щодо доцільності, зокрема, Виборчого кодексу України. На користь його прийняття наводилися такі аргументи: 1) прийняття Виборчого кодексу України сприятиме зведенню до єдиного законодавчого акта різних виборчих законів, що надасть вітчизняному виборчому законодавству більшої системності та упорядкованості; 2) кодифікація виборчого законодавства дозволить уніфікувати спільні для всіх видів виборів принципи виборчого права, засади виборчого процесу, порядок обчислення термінів та порядок здійснення багатьох виборчих процедур; 3) Виборчий кодекс, як свідчить безпосередній досвід реалізації різних видів законодавчих актів, є більш зручною формою для практичного застосування та використання, ніж низка різних виборчих законів; 4) визначені у Виборчому кодексі правила за рахунок їхнього поєднання в одному законодавчому акті є більш доступними та зрозумілими для виборців, членів виборчих комісій та інших суб'єктів виборчого процесу; 5) кодифікація виборчого законодавства дозволить уникнути під час регулювання схожих суспільних відносин, які пов'язані 3 підготовкою та проведення різних видів виборів в Україні, дублювання, виникненню прогалин і колізій; 6) прийняття Виборчого кодексу України є кроком щодо наближення вітчизняного виборчого законодавства до європейських виборчих стандартів і відповідає загальноєвропейській тенденщії, за якої все більше демократичних країн урегульовують виборчі відносини Виборчим кодексом [14].

Позитивні аспекти прийняття Виборчого кодексу вказано зазначались і в чисельних міжнародних документах. Ідеться про Доповідь про виборче законодавство та виборчу адміністрацію в Свропі 2004 р., у якій зауважено, що 3 технічної точки зору краще звести всі закони у єдиний Виборчий кодекс про особливості різних виборів (як загальні аспекти будь-яких виборів, так і в різних ïx частинах). Тому Україні було рекомендовано прийняти єдиний Виборчий кодекс, «... оскільки для громадян він полегшить розуміння, для політичних 
акторів - застосування, для виборчих комісій та судів - роботу з виборчими питаннями» $[18,20]$.

Вивчення зарубіжного досвіду також демонструє, що Виборчий кодекс застосовується багатьма державами Європи і світу (Албанія, Аргентина, Бразилія, Мексика, Болгарія, Боснія і Герцеговина, Республіка Македонія, Бельгія, Іспанія, Люксембург, Молдова, Нідерланди, Норвегія, Польща, Республіка Білорусь, Швеція, Фінляндія, Франція, Філіппіни тощо).

Звісно, ідея упорядкування й систематизації виборчого законодавства шляхом його кодифікації не нова; вона з'явилася в 90-х роках XX ст. Так перша спроба підготовки Виборчого кодексу України була зроблена 16 вересня 1997 р., коли відповідний проект внесено до Верховної Ради України, але він так і не був розглянутий парламентом. Наступна спроба підготовки Виборчого кодексу України - подання 2000 р. Всеукраїнською громадською організацією «Комітет виборців України» проекту Концепщії Кодексу про вибори, референдуми в Україні (Виборчий кодекс України) [13]. Проте, на жаль, цей успішний проект не був завершений... .

Можна вважати, що на шляху удосконалення вітчизняного виборчого законодавства, яке на сьогодні є, до певної міри, розгалуженим та дещо розбалансованим, певним здобутком стало прийняття Виборчого кодексу України 2019 р. Він дозволить упорядкувати та уніфікувати основні виборчі процедури, узгодити діюче виборче законодавство України. Відповідно до його ст. 2, визначено законодавство про вибори. Так підготовка та проведення виборів регулюються Конституцією України, цим Кодексом, законами України «Про Центральну виборчу комісію», «Про Державний реєстр виборців», іншими законами України, а також прийнятими відповідно до них іншими актами законодавства та актами Центральної виборчої комісії.

Проте основне, на наш погляд, щоб його положення були доступними $\mathrm{i}$ зрозумілими, стабільними й дієвими.

Висновки. Історія становлення виборчого законодавства Украӥни демонструє певну позитивну динаміку, трансформаційний еволюційний шлях розвитку. Незважаючи на насиченість і розгалуженість нормативно-правових актів України в даній сфері, часту зміну виборчих систем, конституційне регулювання $\epsilon$ загалом стабільним із часу проголошення незалежної Української держави.

Проведений аналіз дозволяє виокремити такі основні етапи розвитку виборчого законодавства України: 1) до прийняття Конституції України; 2) 31996 до 2004 рр.; 3) з 2004 р. до 2014 рр.; 4) 32015 до 2019 р. Кожен із них відзначається як окремими здобутками, так і прорахунками, певними спробами удосконалення. Безумовно, є сподівання, що 3 прийняттям і набранням чинності Виборчого кодексу України будуть створені реальні можливості реалізації й захисту виборчих прав громадян України, виборчі процедури відповідатимуть існуючим демократичним міжнародним стандартам, слугуватимуть стабільності виборчого законодавства, подальшому утвердженню демократії в Україні. Водночас, на нашу думку, важливо продовжувати дослідження окресленої нами проблематики, особливостей інституту виборів на різних історичних етапах, у різних правових системах. 


\section{Використані джерела:}

1. Конституція (Основний Закон) Української Радянської Соціалістичної Республіки від 20 квітня 1978 року. Відомості Верховної Ради УРСР. 1978. № 18. Ст. 268.

2. Конституція України: прийнята на п'ятій сесії Верховної Ради України 28 червня 1996 року. Відомості Верховної Ради України. 1996. № 30. Ст. 141.

3. Тодыка Ю. Н. Выборы народных депутатов Украины: конституционноправовой аспект. Харків : Факт, 1998. 176 с.

4. Камінська Н. В. Свропейська система місцевого і регіонального самоврядування та Україна: монографія Київ: КНТ, 2014. 414 с.

5. Нестерович $\quad$ В. Ф. Конституційно-правова характеристика хронології проведення виборів у сучасній Україні. Експерт: парадигми юридичних наук $і$ державного управління. 2019. № 1. С. 121-143.

6. Виборче право України: навч. посіб. / за ред. В. Ф. Погорілка, М. І. Ставнійчук. Київ: Парламентське вид-во, 2003. 383 с.

7. Про вибори Президента Української РСР: Закон Української Радянської Соціалістичної Республіки від 5 липня 1991 року № 1297-XII. Відомості Верховної Ради УРСР. 1991. № 33. Ст. 448.

8. Про вибори Президента України: Закон України від 5 березня 1999 р. № 474XIV. Відомості Верховної Ради України. 1999. № 14. Ст. 81

9. Про особливості застосування Закону України «Про вибори Президента України» при повторному голосуванні 26 грудня 2004 року. Закон України URL: https://zakon.rada.gov.ua/

10. Про місцеві вибори: Закон України від 14 липня 2015 року № 595-VIII. Відомості Верховної Ради України. 2015. № 37-38. Ст. 366.

11. Про Центральну виборчу комісію: Закон України від 30 червня 2004 року № 1932-IV. Відомості Верховної Ради Украӥни. 2004. № 36. Ст. 448.

12. Про Державний реєстр виборців: Закон України від 22 лютого 2007 року № 698-V. Відомості Верховної Ради України. 2007. № 20. Ст. 282.

13. Виборчий кодекс України від 19 грудня 2019 року № 396-IX. Верховна Рада України. URL: https://zakon.rada.gov.ua/laws/main/396-IX.

14. Нестерович В. Ф. Проблеми та перспективи прийняття Виборчого кодексу України. Право і суспільство. 2017. № 6. С. 24-29.

15. Концепція Кодексу про вибори, референдуми в Україні (Виборчого кодексу України): проект / Комітет виборців України. Київ: Факт, 2000. 53 с.

16. Марцеляк О. В. Виборче право: сучасне розуміння і сутність. Публічне право. 2011. № 2. C. 12-18.

17. Нестерович В. Ф. Виборче право як підгалузь конституційного права України. Право і суспільство. 2018. № 3. С. 44-49.

18. Ключковський Ю. Б. Виборчі системи та українське виборче законодавство: монографія. Київ: Час Друку, 2011. 132 с.

19. Ключковський Ю. Б. Принщипи виборчого права: доктринальне розуміння, стан та перспективи законодавчої реалізації в Україні: монографія. Київ: Ваіте, 2018. 908 с.

20. Нестерович В. Ф. Роль та місце виборів у державотворенні в Україні. Науковий вісник Дніпропетровського державного університету внутрішніх справ. 2019. № 2. С. 38-46.

21. Дейдей Д. М. Еволюція виборчого законодавства як основи формування представницької влади на місцевому рівні. Інъестиціӥ: практика та досъід 2018. № 24. С. 110-114. DOI: $10.32702 / 2306$. 


\section{References:}

1. Konstytutsiia (Osnovnyi Zakon) Ukrainskoi Radianskoi Sotsialistychnoi Respubliky vid 20 kvitnia 1978 roku. Vidomosti Verkhovnoi Rady URSR-Information of the Supreme Soviet of the USSR, 18, art. 268. [in Ukrainian].

2. Konstytutsiia Ukrainy: pryiniata na p'iatii sesii Verkhovnoi Rady Ukrainy 28 chervnia 1996 roku. (1996) Vidomosti Verkhownoi Rady Ukrainy- Information of the Verkhowna Rada of Ukraine, 30, art. 141. [in Ukrainian].

3. Todyka, Y. N. (1998) Vybori narodnix deputativ Ukrayny: konstytucyonnopravovij aspekt. Xarkiv: Fakt. [in Ukrainian].

4. Kaminska, N. V. Yevropeiska systema mistsevoho i rehionalnoho samovriaduvannia ta Ukraina. Kyiv: KNT. [in Ukrainian].

5. Nesterovych, V. F. (2019) Konstytutsiino-pravova kharakterystyka khronolohii provedennia vyboriv u suchasnii Ukraini. Ekspert: paradyhmy yurydychnykh nauk i derzhavnoho upravlinnya - Expert: the paradigms of law and public administration, 1, 121-143. [in Ukrainian].

6. Vyborche pravo Ukrainy. (2003) V. F. Pogorilk, M. I. Stavnijchuk (Eds.). Kyiv: Parlamentske vyd-vo. [in Ukrainian].

7. Pro vybory Prezydenta Ukrainskoi RSR: Zakon Ukrainskoi Radianskoi Sotsialistychnoi Respubliky vid 5 lypnia 1991 roku № 1297-KhII. (1991) Vidomosti Verkhovnoi Rady URSR - Information of the Verkhovna Rada of Ukraine, 33, art. 448. [in Ukrainian].

8. Pro vybory Prezydenta Ukrainy: Zakon Ukrainy vid 5 bereznia 1999 r. № 474-XIV. (1999) Vidomosti Verkhownoi Rady Ukrainy-Information of the Verkhovna Rada of Ukraine, 14, art. 81. [in Ukrainian].

9. Pro osoblyvosti zastosuvannia Zakonu Ukrainy "Pro vybory Prezydenta Ukrainy" pry povtornomu holosuvanni 26 hrudnia 2004 roku. Zakon Ukrainy URL: https:/ / zakon.rada.gov.ua/ [in Ukrainian].

10. Pro mistsevi vybory: Zakon Ukrainy vid 14 lypnia 2015 roku № 595-VIII. (2015) Vidomosti Verkhoonoi Rady Ukrainy-Information of the Verkhovna Rada of Ukraine, 37-38, art. 366. [in Ukrainian].

11. Pro Tsentralnu vyborchu komisiiu: Zakon Ukrainy vid 30 chervnia 2004 roku № 1932-IV.(2004) Vidomosti Verkhovnoi Rady Ukrainy-Bulletin of the Verkhovna Rada of Ukraine, 36, art. 448. [in Ukrainian].

12. Pro Derzhavnyi reiestr vybortsiv: Zakon Ukrainy vid 22 liutoho 2007 roku № 698-V. (2007) Vidomosti Verkhovnoi Rady Ukrainy-Bulletin of the Verkhovna Rada of Ukraine, 20, art. 282. [in Ukrainian].

13. Vyborchyi kodeks Ukrainy vid 19 hrudnia 2019 roku № 396-IX. (2019) Verkhovna Rada Ukrainy. URL: https:/ / zakon.rada.gov.ua/laws/main/396-IX.

14. Nesterovych, V. F. Problemy ta perspektyvy pryiniattia Vyborchoho kodeksu Ukrainy. Pravo i suspilstvo- Law and society, 6, 24-29. [in Ukrainian].

15. Kontseptsiia Kodeksu pro vybory, referendumy v Ukraini (Vyborchoho kodeksu Ukrainy): proekt Komitetu vybortsiv Ukrainy. Kyiv: Fakt. [in Ukrainian].

16.Martseliak, O. V. (2011) Vyborche pravo: suchasne rozuminnia i sutnist. Publichne pravo- Public law, 2, 12-18. [in Ukrainian].

17. Nesterovych, V. F. Vyborche pravo yak pidhaluz konstytutsiinoho prava Ukrainy. Pravo i suspilstvo-Law and society, 3, 44-49. [in Ukrainian].

18. Kliuchkovskyi, Yu. B. (2011) Vyborchi systemy ta ukrainske vyborche zakonodavstvo. Kyiv: Chas Druku. [in Ukrainian].

19. Kliuchkovskyi, Yu. B. (2018) Pryntsypy vyborchoho prava: doktrynalne rozuminnia, stan ta perspektyvy zakonodavchoi realizatsii v Ukraini. Kyiv: Vaite. [in Ukrainian]. 
20.Nesterovych, V. F. (2019) Rol ta mistse vyboriv u derzhavotvorenni v Ukraini. Naukovyi visnyk Dnipropetrovskoho derzhavnoho universytetu vnutrishnikh sprav-Scientific Bulletin of Dnipropetrovsk State University of Internal Affairs, 2, 38-46. [in Ukrainian].

21. Deidei, D. M. (2018) Evoliutsiia vyborchoho zakonodavstva yak osnovy formuvannia predstavnytskoi vlady na mistsevomu rivni. Investy ciyi: prakty ka ta dosvidInvestment: practice and experience, 24, 110-114. DOI: 10.32702/2306 [in Ukrainian].

Стаття надіӥшла до редколегії 28.11.2019

Диденко О. Н., аспирант кафедры конституционного права и прав человека Национальной академии внутренних дел (г. Киев, Украина)

\section{ЭВОЛЮЦИЯ РАЗВИТИЯ ИЗБИРАТЕЛЬНОГО ЗАКОНОДАТЕЛЬСТВА УКРАИНЫ}

В статье раскрываются особенности становления избирательного Законодательства Украины со времени провозглашения независимости нашего государства. Выделены определенные тенденции и закономерности его эволюционного пути развития. Так, выборы Президента Украины, народных депутатов Украины, как и местные выборы органов и должностных лиц местного самоуправления проводились преимущественно на основе новых законов или их новых редакций, апробуючи разные виды избирательных систем. Выделены определенные этапы и позитивная динамика к стабильности избирательного законодательства Украины в последние годы. Подчеркнуто значение Избирательного кодекса Украины для упорядочивания данной отрасли законодательства, гармонизаци с существующими международными стандартами в сфере данной, а также перспективные направлений усовершенствования избирательного законодательства.

Ключевые слова: выборы, законодательство, периодизация, право избирать, выборы Президента Украины, местные выборы, Избирательный кодекс Украины.

Didenko O.,

Postgraduate Student of Constitutional

Law and Human Rights

National Academy of Internal Affairs

(Kyiv, Ukraine)

\section{EVOLUTION OF DEVELOPMENT OF ELECTORAL LEGISLATION OF UKRAINE}

In the article the features of becoming of electoral legislation of Ukraine open up since proclamation of independence of our state. Certain tendencies and confo-rmities to law of him are distinguished evolutional way of development.

Elections of President of Ukraine, deputies of people's of Ukraine, as well as local elections of organs and public servants of local self-government were conducted mainly 
on the basis of new laws or them new releases, approving different types of the electoral systems. For the last almost thirty years more than twenty electoral campaigns took Place and, as see, from the higher brought list over of laws that regulated elections in Ukraine, then obvious substantial differences are in the existent electoral systems, public and local self-government authorities to that elections, electoral process and others like that. As Constitution of Ukrainian SSR and some laws of Ukrainian SSR operated, new laws were accepted, repeatedly made alteration and additions in existent normatively-legal acts in the field of given.

To our opinion, a ponderable value for development of electoral legislation,had an acceptance of Constitution of Ukraine 1996; what entailed activation of acceptance of the special laws. The certain stages and positive dynamics are distinguished to stability of electoral legislation of Ukraine in recent year. The value of the Electoral code of Ukraine is underline for arrangement of this industry of legislation, harmonization with existent international standards in the field of given, andalso perspective dire-ctions of improvement of electoral legislation.

Key words: elections, legislation, division into periods, right to elect, elections of President of Ukraine, local elections, Electoral code of Ukraine.

DOI: 10.33766/2524-0323.88.45-55

УДК 341.3; 342.4

А. Я. Палюх, докторант кафедри конституційного права та прав людини Національної академії внутрішніх справ (м. Київ, Україна)

e-mail: andrewpaliuch@gmail.com iDhttps:/ / orcid.org/0000-0001-9856-9147

\section{ЗАБЕЗПЕЧЕННЯ ЗДОРОВОГО СПОСОБУ ЖИТТЯ ТА ПРАВО НА ОХОРОНУ ЗДОРОВ'Я: ТЕОРЕТИЧНІ Й КОНСТИТУЦЙНО-ПРАВОВІ ОСНОВИ}

Урегулювання права людини на охорону здоров'я на конституційному рівні часто пов'язується 3 іншими правами людини і громадянина, різноманітними сферами життєдіяльності як в Україні, так і в багатьох зарубіжних державах. Зокрема, це стосується медичного обслуговування, фізичної культури і спорту, освіти і науки тощо. Проблеми реалізації даного права негативно відбиваються на створенні умов і забезпеченні здорового способу життя особи, громади і нації, тому на основі теоретичного вивчення, аналізу конституційно-правового регулювання досліджено поняття і природу таких категорій як здоров'я, право на охорону здоров'я, здоровий спосіб життя, а також їх співвідношення та напрями вдосконалення.

Ключові слова: здоров'я, право на охорону здоров'я, здоровий спосіб життя, фізична культура, законодавство, конституція.

Постановка проблеми. Рівень благополуччя населення, його фізичного і психічного здоров'я відіграє важливу соціальну, економічну та інші ролі для особи, суспільства і держави. Забезпечення права людини на здоров'я, поряд із іншими важливими основоположними правами і свободами людини й 